\title{
ON THE Hypothesis OF IGE AgES SUGgested By CAPTAIN E. S. GERNET
}

\author{
By О. Р. Сhizhov \\ (Institut Geografii Akademii Nauk SSSR, Moscow V-r 7, U.S.S.R.)
}

\begin{abstract}
This paper is devoted to the causes of initiation and development of the Quaternary glaciation and climatic fluctuations connected with it. There are many hypotheses on this problem. The most interesting of them are those suggesting the evolution of glaciers and ice sheets, and variation of climate as a selfregulating process.

The first person to offer a definite mechanism for such self-regulation was the Russian sailor, Captain E. S. Gernet, whose book about this was published in 1930 . The book is of great scientific importance, but so far few people appear to have known anything about it. This paper gives a brief summary of the book, shows the similarity between the main ideas of Captain Gernet and the American geologists, W. L. Stokes, M. Ewing and W. L. Donn (the theory of the two latter authors has become well known recently), and justifies naming this concept after Gernet and Stokes in honour of the men who first proposed it.
\end{abstract}

RÉsumÉ. Sur de nouvelles idées des âges glaciaires et sur les hypothèses faites par Capitaine E. S. Gernet il y a quelques années. Le présent article traite des causes de l'origine et du développement de la glaciation quaternaire et des fluctuations climatiques connexes. Il existe bien des hypothèses sur ce problème. Les plus intéressantes sont celles qui suggèrent que l'évolution des glaciers et indlandsis, et la variation du climat consistent en un processus d'auto-régulation.

La première personne qui présenta un mécanisme définitif pour une telle auto-régulation fut le navigateur russe, Capitaine E. S. Gernet, dont le livre sur ce sujet a été publié en r93o. Ce livre est d'un grand intérêt scientifique, mais jusqu'à présent, bien peu de personnes en ont eu connaissance. Le présent article donne un bref résumé de cet ouvrage, montre la similitude entre les idées maîtresses de Capitaine Gernet et des géologues américains W. L. Stokes, M. Ewing et W. L. Donn (la théorie de deux derniers auteurs est bien connue), et justifie la dénomination d'hypothèse de Gernet-Stokes en honneur de ceux qui, les premiers, l'ont proposée.

Zusammenfassung. Eine neue Eiszeittheorie, vor Jahren entwickelt durch Kapitän E. S. Gernet. Dieser Aufsatz ist der Erklärung des Beginns und Ablaufs der quartären Vergletscherung und der damit verbundenen Klimaschwankungen gewidmet. Es gibt viele Hypothesen zu diesem Problem. Die interessantesten darunter sind jene, die in der Entwicklung der Gletscher und Eisschilde und der Änderung des Klimas einen sich selbst regulierenden Vorgang sehen.

Der erste, der einen bestimmten Mechanismus dieser Selbstregulierung aufzeigte, war der russische Seeman Kapitän E. S. Gernet, dessen Buch darüber r 930 veröffentlicht wurde. Das Buch ist von grosser wissenschaftlicher Bedeutung, aber bisher nur wenigen bekannt. Dieser Aufsatz gibt eine kurze Zusammenfassung des Buches, zeigt die Ähnlichkeit der Grundideen von Kapitän Gernet mit denen der amerikanischen Geologen W. L. Stokes, M. Ewing und W. L. Donn (die Theorie der beiden letztgenannten Autoren ist kürzlich bekannt geworden) und rechtfertigt die Benennung des Konzepts nach Gernet-Stokes, zu Ehren der Männer, die sie als erste vorgeschlagen haben.

IN 1956 and 1958 papers were published by the two well-known American geologists M. Ewing and W. L. Donn, who proposed a new theory of ice ages and suggested some evidence to prove it. The theory (it should perhaps be called an hypothesis) has spread all over the world and it is often called the Ewing-Donn theory. In I 966 they published their theory in a revised form (Donn and Ewing, 1966). But in fact they were not the first scientists to offer such a concept. All those problems were set up and solved correctly (in principle) by Captain E. S. Gernet many years ago.

In 1930, in Tokyo, Gernet published at his own expense the little book The ice lichens, a new theory of ice ages. This book, written in Russian, became a collectors' item long ago. Nobody knows of it in the western countries and only a few people know of it in the U.S.S.R. The famous writers, Maxim Gorkiy and Konstantin Paustovskiy, had read Gernet's book and were greatly impressed by it, but it remained almost unnoticed by the scientists.

Gernet's book consists of six chapters (122 pages). The most important of them are chapters 2 and 3 , in which the author offers his own hypothesis and grounds for his ice-lichen theory. The general lines of this hypothesis are as follows: (i) the normal conditions on the Earth's surface are non-glacial ones; the ice, having appeared and spread over the surface of the globe, produced later a glacial climate; (ii) the glaciers first formed as a consequence of the 
uplift of the continents during the Tertiary; (iii) the evolution of glaciers and ice sheets (or "ice lichens", as the author calls them) is a self-regulating process; ice lichens, spreading over the Earth's surface, are like the disease of the planet.

The author introduced some new ideas. They are: "the extra-snow layer" of the atmosphere, and its "lower limits" and "upper limits". These same ideas were later introduced into glaciology by the well-known geographer Kalesnik (I939), who referred to the chionosphere (snowsphere) and its lower and upper limits. The extra-snow layer is a layer in which the quantity of annual snowfall is greater than its annual melting, and where the remnants of the snow can remain throughout the whole summer until the following winter. At the lower and upper limits of the extra-snow layer the quantity of annual snowfall is equal to the annual melting and evaporation of snow. Where it intersects the Earth's surface, the lower limit of the extra-snow layer forms the snow line. The lower limit of the extra-snow layer (or potential snow line) is higher (in altitude) in low latitudes and lower in high ones. When uplift of the Earth's crust creates a dome with gentle slopes and the top of the dome is elevated slightly above the lower limit of the extra-snow layer, then a snow patch remaining all the year round would form there. Because of its gradual growth and the action of the wind which carries the snow away from the top onto the slopes, the snow patch tends to spread. The existence of such a snow patch tends to lower the limit of the extra-snow layer above it. Accordingly, conditions for the survival of the snow patch improve, and its area and thickness increase steadily. Gradually the snow patch becomes transformed into an ice sheet or "ice lichen". (Ideas very similar to those of Gernet can be found in a short paper by Hawkes (1947), but he gives no definitions of extra-snow layer, etc. as Gernet does, and he draws no further conclusions on the evolution of glaciation.)

An elevation that as a result of its epeirogenic uplift reaches the limit of the extra-snow layer and then rises slightly higher above it is named by Gernet an "ice-bearing elevation". The formation of a snow patch (or patches) on an ice-bearing elevation and its subsequent development into an ice sheet is very probable in the polar regions where the limit of the extrasnow layer is relatively low. If an ice-bearing elevation occurs on a large island (or small continent) surrounded by ocean (such as the Antarctic continent), the ice sheet so formed will reach the shores and become stationary. The ice sheet calves icebergs which float out into the ocean and melt sooner or later. Gernet refers to such an ice sheet as a "stationary ice lichen".

If ice sheets are formed on continents which are large enough and if they surround a sea lying inside them (like the Arctic Ocean), the ice sheets will reach this Polar Sea and begin to calve many icebergs into it from their northern areas and they will spread southward into lower latitudes where their melting will increase. The quantity of icebergs that the Arctic Ocean receives becomes greater and greater, and the temperature of the water decreases. At last the whole surface of the Arctic Ocean will become full of ice and it will freeze. Then the Arctic Ocean becomes an ice continent which is very cold and dry. The accumulation of snow on the whole of the ice sheet becomes less than melting in the southern areas which are situated in lower latitudes and then retreat of the ice begins.

In the same way as the advance of ice makes the climate colder, so the retreat of ice makes it warmer. The retreat stage lasts up to the moment when accumulation exceeds melting which occurs after the Arctic Ocean becomes free of ice. Then the above-mentioned cycle begins again.

Gernet has laid emphasis on iceberg formation. He considers it possible that a portion of the icebergs derived from ice sheets, and carried partly into the Arctic Ocean to remain there, was carried by cold currents to drift southward like an ice river. They could make the climate colder and lower the limit of the extra-snow layer on the shores near such an iceberg current, and thereby create some "reflective ice-bearing elevations" where ice sheets formed.

An ice sheet that has periodical pulsations (and such a case we have in the Northern Hemisphere) is called by Gernet an "ice lichen limited by its pulsation". The original creation of such an ice sheet (or ice lichen) Gernet supposed to have occurred in Greenland. 
The greatest ice lichen of the Northern Hemisphere is situated there at present and its pulsations can explain the glacials and interglacials.

In the following chapter the author restores the pre-glacial temperature on the Earth's surface and explains the present-day differences from it. The "polar ice caps" are responsible for this.

The largest ice lichens we have at present are the Greenland and Antarctic ice sheets. The evolution of glaciation is quite different in the Southern and Northern Hemispheres because of differences in the geographical situation in southern and northern polar regions; in the south there is a large continent surrounded by ocean, and in the north the mediterranean Polar Sea is surrounded by continents.

As a conclusion to the last chapter, Gernet appeals for the necessity of mankind destroying the Greenland ice sheet. This was responsible for spreading ice lichens over Europe and North America in the past, and it should be a similar cause in the future, which is not so far away because we are living at the end of the present interglacial. If the Greenland ice lichen is destroyed, a climate like that of the Miocene will be created and bring a general warming-up, fertile fields, etc. in northern Canada and Siberia. If it is not destroyed, then the horror of a new ice age awaits mankind. Gernet proposed to destroy the Greenland ice sheet gradually; he would arrange for this by systematic annual clearing of the ice sheet of the quantity of snow that had fallen during that year. Then the accumulation of snow on the ice sheet would become equal to zero and the volume of ice would diminish each subsequent year.

This project and everything connected with it may give the reader the impression of something fantastic and unscientific. But it is not this which is of great importance in the book. When we have a really well-proved theory of ice ages (we have not got it yet), we shall be able to evaluate Gernet's and other authors' projects (like Borisov's (r962) one) for the improvement of climate. Later (but before Ewing and Donn published their theory), an American geologist Stokes ( I 955) gave his "ocean control theory", which was indeed "Another look at the Ice Age" (the title of his work). Of course, Stokes did not know anything about Gernet when he was writing his paper, but his concept is almost the same in its main principle as Gernet's one.

Stokes does not write so much as Gernet about the role of icebergs but he places importance on cooling and warming of the ocean waters during the glacial and interglacial stages, respectively.

The main ideas proposed by Gernet and Stokes are:

(i) The origin of glaciers and ice sheets can be easily explained by the formation of high mountains and continents during the Tertiary and the application of orographic hypotheses which had been expounded years ago.

(ii) Glaciation is a phenomenon that greatly influences the climate of the Earth. It creates its own glacial climate which is favourable to it alone, and because of this it is a self-regulating process.

(iii) Glacial evolution is directly connected with the ocean which in turn controls the continental ice. The ocean is the source of moisture; it gives rise to snowfall on glaciers and ice sheets. When the ocean is warm, the snowfall over ice sheets is heavy and they advance. When it cools because of spreading of the continental ice, evaporation from its surface decreases and becomes very little when ice covers the ocean surface. It therefore results in a decrease of snow accumulation on continental ice sheets and they consequently retreat.

(iv) The different relationship between land and sea in the southern and northern polar regions is the reason for different glacial evolution in the Southern and Northern Hemispheres. * This concept had already been explained by Brooks (1926), and it has been developed in many respects in later works (Bonacina, I947; Budyko, I96 I, I 962 [a], [b]; Šegota, I963; Shumskiy and others, [ ${ }^{\mathrm{C}}$ I964]; Sergin and Sergin, I 966).

* This is discussed by Gernet, but it is beyond the scope of the paper by Stokes. 
But only Gernet and Stokes, and later Ewing and Donn, have expressed the concept discussed above more definitely. The latter authors have given many details and new evidence in support of the theory in their papers. Their point of view differs from the concept of Stokes and Gernet only in the understanding of the original cause of the appearance of glaciers on the Earth's surface. Ewing and Donn consider that glaciers are initiated by displacement of the poles. When the poles were situated in the open ocean glaciation was impossible, but when they are displaced to their present positions it becomes very probable and, as we know, actually exists in both polar regions. But one can see that from the glaciological point of view both explanations have just the same meaning. There is no difference in the probability of inception and development of glaciers between the uplift of the Earth's crust at the polar regions and the displacement of the higher parts of the crust to those regions.

Everything that has been mentioned above indicates the necessity and justice for naming this the Gernet-Stokes hypothesis after the men who first proposed it.

\section{MS. received 24 May 1966 and in revised form 24 May 1968}

\section{REFERENCES}

Bonacina, L. C. W. 1947. The self-generating or automatic process in glaciation. Quarterly fournal of the Royal Meteorological Society, Vol. 73, Nos. 315-16, p. 85-88.

Borisov, P. M. 1962. K probleme korennogo uluchsheniya klimata [On the problem of the improvement of climate]. Izvestiya Vsesoyuznogo Geograficheskogo Obshchestva, Tom 94, Vyp. 4, p. 304-18.

Brooks, C. E. P. 1926. Climate through the ages: a study of the climatic factors and their variations. London, Ernest Benn Ltd. [Revised edition. London, Ernest Benn Ltd., 1949.]

Budyko, M. I. 196r. O termicheskoy zonal'nosti Zemli [On the thermic zonality of the Earth]. Meteorologiya $i$ Gidrologiya, 1961, No. 11, p. 7-14.

Budyko, M. I. I962[a]. Polyarnyye l'dy i klimat [Polar ice and climate]. Izvestiya Akademii Nauk SSSR. Seriya Geograficheskaya, i962, No. 6, p. 3-10.

Budyko, M. I. I $962[\mathrm{~b}]$. Teplovoy rezhim Zemli [The heat regime of the Earth]. Priroda, 1962, No. 8, p. 55-59.

Donn, W. L., and Ewing, M. 1966. A theory of ice ages. III. Science, Vol. 152, No. 3720, p. $1706-12$.

Ewing, M., and Donn, W. L. 1956. A theory of ice ages. [I.] Science, Vol. 123, No. 3207, p. 1061-66.

Ewing, M., and Donn, W. L. 1958 . A theory of ice ages. II. Science, Vol. 127 , No. 3307, p. I1 $159^{-62}$.

Gernet, E. S. 1930. Ledyanyye lishayi, novaya lednikovaya teoriya, obshchedostupno izlozhennaya [The ice lichens, a new theory of ice ages]. Tokyo, E. S. Gernet.

Hawkes, L. 1947. Self-preserving glaciers. Quarterly Journal of the Royal Meteorological Society, Vol. 73, Nos. 31 5-16, p. 89-90.

Kalesnik, S. V. r939. Obshchaya glyatsiologiya [Glaciology]. Leningrad, Uchpedgiz (Uchelno-Pedagogicheskoye Izdatel'stvo).

Šegota, T. 1963 . Geografske osnove glacijacija [The geographical foundation of glaciology]. Radovi. Geografskog Instituta, Sv. 4, Zagreb, Vol. 4, 119 p. [See also the English abstract in Bulletin Scientifique. Conseil des Académies de la RPF Yougoslavie, Tom. 6, No. $3,196 \mathrm{1}$, p. 75.]

Sergin, S. Ya., and Sergin, V. Ya. 1966. Zemnaya poverkhnost-atmosfera, kak sistema avtomaticheskogo regulirovaniya [Earth surface-atmosphere as a self-regulating system]. Materialy Glyatsiologicheskikh Issledovaniy. Khronika. Obsuzhdeniya, No. 12, p. 171-89.

Shumskiy, P. A., and others. [ ${ }^{\mathrm{I}}{ }^{1964 .}$.] Ice and its changes, by P. A. Shumskiy, A. N. Krenke and I. A. Zotikov. (In Odishaw, H., ed. Research in geophysics. Vol. 2. Solid earth and interface phenomena. Cambridge, Mass., Massachusetts Institute of Technology Press, p. 425-6o.)

Stokes, W. L. 1955. Another lcok at the Ice Age. Science, Vol. 122, No. 3174, p. 815-21. 